\title{
Reviving Federal Grand Jury Presentments
}

\author{
Renée B. Lettow
}

No person shall be held to answer for a capital, or otherwise infamous crime, unless on a presentment or indictment of a Grand Jury . ...

In March 1992, Rockwell International pled guilty to five environmental felonies and five misdemeanors connected with its Rocky Flats plant, which manufactured plutonium triggers for nuclear bombs. Prosecutors were elated; the $\$ 18.5$ million fine was the largest environmental crimes settlement in history. The grand jury, however, had other ideas. The majority of the grand jurors wanted to indict individual officials of both Rockwell and the Department of Energy (DOE), but the prosecutor had resisted individual indictments. So the grand jury, against the prosecutor's will, drew up its own "indictment" and presented it to the judge. ${ }^{2}$ Its action has confounded legal scholars: what is the status (or even the correct name) of this document?

The consternation this question has caused is a measure of the confusion surrounding grand jury law. Although grand juries had considerable independence and were a major avenue for popular participation in the early Republic, their powers have dwindled. Courts have clouded the issue by periodically reasserting the grand jury's traditional powers, then suppressing them again. The Supreme Court has largely been silent.

The number of recent articles praising grand juries points to a revival of interest in this institution. Commentators see the grand jury as an antidote to citizens' alienation from their government. One author urges the recreation of administrative grand juries. ${ }^{3}$ Another argues for an expansion of the grand jury's reporting function. ${ }^{4}$ When she was a state's attorney, Attorney General Reno made a point of using grand juries to investigate social ills in Florida. ${ }^{5}$

1. U.S. CONST. amend. V.

2. See infra Part II.A.

3. Ronald F. Wright, Why Not Administrative Grand Juries?, 44 ADMIN. L. REV. 465 (1992).

4. Barry J. Stem, Revealing Misconduct by Public Officials Through Grand Jury Reports, 136 U. PA. L. REV. 73 (1987). In the early years of the Republic, all documents that the grand jury itself drafted were called presentments. However, this usage was not technically correct. In theory, presentments were and are accusations of criminal conduct only; other documents are reports. See Note, 54 TEX. L. REV. 663, 664-65 (1976).

5. During Janet Reno's service as a state's attorney, Dade County grand jurors investigated, among other matters, homelessness, child welfare, public housing, hurricane preparation, firearms regulation, and hazardous waste. Terry Eastland, Attorney General and Social Worker, WALL ST. J., Mar. 10, 1993, at A15. A spokesman for Reno said that "when a government agency is 'dysfunctional' or an industry is 'acting irresponsibly' or 'any function of our community' is at risk, the grand jury looks into it." Id. As one grand 
Despite this growing interest, however, no one has recently discussed resurrecting the federal grand jury's presentment power. ${ }^{6}$ At common law, the presentment function was at least as important as the indictment; its inclusion in the Constitution shows its significance to the Framers.

A presentment is a charge the grand jury brings on its own initiative. In contrast, an indictment is almost always first drawn up by a prosecutor and then submitted to the grand jury for approval. In federal courts, a presentment cannot by itself initiate a prosecution. To begin a prosecution, the prosecutor must sign the document. ${ }^{7}$ The act of signing, which is wholly within the Executive's discretion, transforms the presentment into an indictment. While a presentment is capable of serving as a formal charging document, its main function is to publicize. The Federal Rules of Criminal Procedure, however, prevent the grand jury from publicizing its conclusions by giving the judge discretion to seal documents such as presentments.

Although restoring the presentment power would therefore not automatically initiate a prosecution of Rockwell and DOE officials, the publicity of a grand jury accusation would serve three key goals. First, allowing presentments of government officials and contractors would check prosecutors' tendency to favor other members of the executive branch. The grand jury, a body of private citizens, is more likely to be free from bias than a politically beholden prosecutor; it can avoid even the appearance of impropriety. Second, presentments would prevent frustration and disillusionment among citizens who are told to act independently, who perform long hours of public service, and whose opinion is then suppressed because of a plea bargain. Not surprisingly, the Rocky Flats grand jury was bitter at not even being able to express its opinion after a two-and-a-half-year investigation. Third, if jurors could take a more active role in the administration of justice, they would grow in their knowledge of public affairs and in their attachment to American democracy.

Part I of this Note examines the origins and modern fate of the federal grand jury presentment power. In the early Republic, the power was frequently used; in the nineteenth and twentieth centuries it declined and became mired in confusion. The Federal Rules of Criminal Procedure, promulgated by the Supreme Court in 1945, affirmed and hastened this decline. The Rules deliberately make no provision for presentments; they ignore the Constitution's language. Part I then turns to subsequent decisions and the current muddled

juror put it, "We act as the conscience of this community." Id.

6. See United States v. Cox, 342 F.2d 167, 196 (5th Cir. 1965) (Wisdom, J., concurring specially) (advocating characterization of document as "presentment"); In re Presentment of Special Grand Jury Impaneled January, 1969, 315 F. Supp. 662, 678 (D. Md. 1970) (permitting disclosure of presentment); Note, supra note 4, at 672 (applauding holding of In re Presentment of Special Grand Jury Impaneled January, 1969).

7. See infra text accompanying note 66 . 
state of federal grand jury presentment law. Part II discusses the Rocky Flats case, including the specific factors that prompted the grand jurors' revolt and their frustration with the criminal justice system. Part III suggests steps for safe revival of the presentment power. These include limiting presentments to government officials and contractors, providing for declaratory judgment at the option of the accused, and allowing the grand jury appropriate staff and protection from early discharge.

\section{The History of the Federal GRAND JURY PRESENTMENT Power}

The history of federal grand jury powers is the story of descent into confusion. In emphasizing the grand jury's function as a shield against government oppression, historians have glossed over its use as a sword. Before the Constitution, the colonies relied heavily on grand juries to perform accusatorial, administrative, and even legislative functions. Early federal grand juries remained spirited and regularly issued presentments. In the twentieth century, however, grand jury law became murkier, particularly with the passage of the Federal Rules of Criminal Procedure. Lawyers and judges now doubt the existence, let alone the extent, of the presentment power.

\section{A. Background: The Grand Jury Before the Constitution}

The grand jury was a creation of English medieval law carried to the American colonies and later formally enshrined in the United States Constitution. By including the grand jury in the Bill of Rights, the United States inherited not only the institution's defensive function, but also its accusatory function. ${ }^{8}$ Indeed, the common law oath of a grand juror "says not a single word about indictments; on the contrary, at common law the grand jury swore to 'diligently inquire and true presentments make."' In 1758, Blackstone gave the classic definition of a presentment:

A presentment, properly speaking, is the notice taken by a grand jury of any offence from their own knowledge or observation, without any

8. Established by Henry II's Assize of Clarendon in 1166, the grand jury's original function was to bring accusations before royal judges. At first all accusations originated with the grand jury, but later the jurors considered accusations from outsiders and passed upon indictments drawn up by crown prosecutors. The jurors, however, retained the power to accuse on their own initiative. Such an accusation was called a presentment. See 1 WilliaM S. HOLdSWORTH, A HISTORY OF ENGliSH LAW 147-48 (1908); 2 FREDERICK POLLOCK \& FREDERIC W. MAITLAND, THE HISTORY OF ENGLISH LAW 641-42 (photo. reprint 1982) (1898); 4 JAMES F. STEPHEN, COMMENTARIES ON THE LAWS OF ENGLAND 243-44 (21st ed. 1950); 2 JOSEPH STORY, COMMENTARIES ON THE CONSTITUTION OF THE UNITED STATES 590-93 (Boston, Little, Brown, 3d ed. 1858).

9. In re Presentment by Camden County Grand Jury, 89 A.2d 416, 426 (N.J. 1952) (quoting Rex v. Shaftsbury, 8 Howell's State Trials 759 (1681)); see Hale v. Henkel, 201 U.S. 43, 60 (1906) ("This oath has remained substantially unchanged to the present day."). 
bill of indictment laid before them at the suit of the king. . . upon which the officer of the court must afterwards frame an indictment, before the party presented as the [perpetrator] can be put to answer it. $^{10}$

Although historians chiefly celebrate the English grand jury for refusals to indict in the late seventeenth century, ${ }^{11}$ grand juries also won respect for making accusations against the Crown's desires. Grand juries took advantage of their wide investigative powers and gained prominence in fighting government corruption by issuing presentments against royal officials. ${ }^{12}$

The same pattern of grand jury independence crossed the Atlantic to the colonies. Indeed, since the colonies lacked an efficient constabulary, colonial grand juries exercised greater independence than their English counterparts. ${ }^{13}$ American grand juries had a penchant for presenting government officials. These presentments could be for crimes or noncriminal violations of the public trust. The latter type of accusation would now, and sometimes then, be called

10. 4 William BlaCKStone, COMmEnTARIES *298 (footnote omitted). According to Blackstone, therefore, the accused could not be put to trial unless an official drew up an indictment. The "officer of the court" may have had limited discretion as to whether to frame an indictment. See SIDNEY \& BEATRICE WEBB, ENGLISH LOCAL GOVERNMENT FROM THE REVOLUTION TO THE MUNICIPAL CORPORATIONS ACT: THE PARISH AND THE COUNTY 308 (1906) ("The officer or locality 'presented' might be formally indicted ...." (emphasis added)). Before a regular system of public prosecution was established, the officer was likely to have been the clerk of the court, JuLIUS GOEBEL JR. \& T. RAYMOND NAUGHTON, LAW ENForcement in Colonial New YoRK: A STUdy in Criminal Procedure (1664-1776) 352 (1944), or a justice of the peace, YALE KAMISAR ET AL., MODERN CRIMINAL Procedure 635 (7th ed. 1990). Given the court clerk's limited knowledge of the locale and the limited resources of justices of the peace, it is likely that framing an indictment based on the grand jury's accusation was usually automatic. This was virtually the case in the American colonies, generally. RICHARD D. YOUNGER, THE PEOPLE'S PANEL: THE GRAND JURY IN THE UNITED STATES, 1634-1941, at 5-6 (1963). In the colonial New York Supreme Court, the Attorney General reduced the presentment to form. In other courts, either a deputy attorney general or the clerk of the peace performed this task. GOEBEL \& NAUGHTON, supra, at 352-53. Interestingly, the New York Courts of Sessions exercised considerable discretion over prosecution: "If the Crown's representative refused to draw the indictment, the court would order someone else to do so." Id. at 353. The court also occasionally quashed presentments rather than ordering them to be put in form. Id.

By the late eighteenth century in England, constables had gradually taken more initiative in making accusations. 4 HOLDSWORTH, supra note 8, at 144-45 (1924); YOUNGER, supra, at 5.

11. In 1681, a grand jury refused to indict the Earl of Shaftsbury, a supporter of the Protestant cause, on charges of treason. Rex v. Shaftsbury, 8 Howell's State Trials 759 (1681); see Helene E. Schwartz, Demythologizing the Historic Role of the Grand Jury, 10 AM. CRIM. L. REV. 701, 710-21 (1972); Comment, Federal Grand Jury Secrecy, 5 GoNZ. L. REV. 255, 256 (1970).

12. In the seventeenth and eighteenth centuries, English grand juries criticized justices of the peace who accepted excessive fees, constables who were lax in enforcing the law, and other officials who failed to maintain bridges, jails, highways, and other county property. Often these accusations did not include charges of criminal wrongdoing, but many of these breaches of the public trust would be criminal today. WEBB, supra note 10, at 448-56; see also 10 HOLDSWORTH, supra note 8, at 146-51 (1938). This function of watching over public officials was ancient even then. In the thirteenth century, the justices in eyre (on circuit) carried with them a list of questions, called the Articles of the Eyre, to ask local grand juries. "[A] large group of articles relates to the official misdoings of royal officers, sheriffs, coroners and bailiffs." POLLOCK \& MAITLAND, supra note 8, at 520-21.

13. Grand juries also took on many administrative roles. In certain colonies grand juries could determine the amount of compensation for land taken for public purposes. Where local courts collected taxes, grand juries set rates and helped gather the taxes. See Wright, supra note 3, at 473 . 
a report. ${ }^{14}$ Colonies that lacked a representative legislature often turned to grand juries as a substitute; grand juries regulated areas higher officials did not address. ${ }^{15}$ As tensions between the colonies and the mother country grew, grand juries played an increasingly prominent role. They not only refused to indict, ${ }^{16}$ but also issued angry and well-publicized presentments and indictments against British officials and soldiers. ${ }^{17}$ Because of its boldness and independence in both defending and accusing, the grand jury emerged from the Revolution with enhanced prestige.

\section{B. Federal Grand Juries in the Early Republic}

Although historians typically portray early federal grand juries as mere tools of the central government, ${ }^{18}$ an examination of actual charges and presentments reveals a different picture. ${ }^{19}$ After the Constitution's ratification, grand jurors continued to take initiative in making presentments.

Given that the Federalists wanted to assuage Anti-Federalist fears of a powerful central government, it is not surprising that ratification documents emphasized the grand jury's shield rather than its sword. ${ }^{20}$ Early post-

14. The first regular American grand jury, that of the Massachusetts Bay Colony in 1635, took its mission seriously. After listening to the Ten Commandments and hearing Governor John Winthrop's charge to present all crimes and misdemeanors that came before them, the jurors proceeded to present more than a hundred offenders, including several colonial magistrates. Other colonial grand juries followed their example. Plymouth grand juries were especially eager to present officials. YOUNGER, supra note 10, at 6-7.

15. New York grand juries were particularly active in legislating and regulating, since New York lacked any other representative body after the Duke of York abolished the Assembly upon his accession to the throne. In 1688, an Albany grand jury required anyone selling spirits to keep lodging for men and horses. Another New York grand jury prohibited riding over cornfields. GoEBEL \& NAUGHTON, supra note 10 , at 336, 355-56, 361. Colonial methods of grand juror selection gave the jurors considerable legitimacy as lawmakers. In one model, exemplified by Massachusetts, jurors were elected from each town; in another, the local elected sheriff or the court selected grand jurors, usually from a pool of the wealthiest and most respected men of the area. Wright, supra note 3, at 474-75.

16. The American equivalent of the Earl of Shaftsbury's case was the Crown's unsuccessful attempt to indict John Peter Zenger for seditious libel. Zenger, a journalist, had published articles criticizing William Cosby, the English governor of New York. When the Governor sought indictments against Zenger in 1734, the grand jury twice refused to indict. Zenger was finally prosecuted by information and acquitted. Richard H. Kuh, The Grand Jury "Presentment": Foul Blow or Fair Play?, 55 COLUM. L. REV. 1103, 1108-09 (1955); see also Leroy D. CLARK, THE GRAND JURY 18 (1975); MARVIN E. FRANKEL \& GARY P. NAFTALIS, THE GRAND JURY: AN INSTTTUTION ON TRIAL 11 (1975); CHARLES F. HEARTMAN, ChaRLeS F. HEARTMIAN PRESENTS JOHN PETER ZENGER AND HIS FIGHT FOR THE FREEDOM OF THE AMERICAN PRESS (1934). The above authors disagree on the dates of the attempted indictments.

17. In 1769 , for example, the Boston grand jury accused soldiers quartered in the town of "breaking and entering dwellings, waylaying citizens, and wounding a justice of the peace . ..."The attorney general refused to prosecute, whereupon the Massachusetts Assembly vigorously denounced him, and the grand jury, in revenge, rejected all bills of indictment laid before it. YOUNGER, supra note 10, at 29-31.

18. See, e.g., id. at 47 ("Federal grand juries ... tended to become instruments of the central government rather than representatives of the people.").

19. Early federal grand jury presentments have been collected and published in 2 THE DOCUMENTARY HISTORY OF THE SUPREME COURT OF THE UNITED STATES, 1789-1800 (Maeva Marcus ed., 1988) [hereinafter DOCUMENTARY HISTORY]; 3 id. (Maeva Marcus ed., 1990).

20. See 2 DEBATES ON THE ADOPTION OF THE FEDERAL CONSTITUTION 110 (Jonathan Elliot ed., 1987) (1888) (the Massachusetts debates, Mr. Holmes); "Hampden," Letter to Mr. Russell, MASs. CENTINEL, Jan. 26, 1788, reprinted in 4 THE COMPLETE ANTI-FEDERALIST 198, 200 (Herbert J. Storing ed., 1981). Having 
ratification charges to and writings about the federal grand jury, however, reveal an equal if not greater concern for the sword. Without fail, judges and justices reminded grand jurors of their oaths to make diligent inquiries and true presentments. ${ }^{21}$ Indeed, judges mentioned presentments more often than indictments. In his charge to the first grand jury impaneled for the Circuit Court for the district of Delaware, Justice Wilson urged grand jurors: "[Y]ou will be sedulous that criminals be discovered and punished, and you will be equally sedulous that the innocent be guarded and protected. With regard to both, it will be your zealous effort, as it is your unquestionable right, to make diligent enquiries, and to offer true presentments." 22 In a lecture to students at the University of Pennsylvania, the Justice emphasized the grand jury's independence from the prosecutor:

[Grand jurors] are not appointed for the procecutor [sic] or for the court: they are appointed for the government and for the people: and of both the government and people it is surely the concernment, that ... all crimes, whether given or not given in charge, whether described or not described with professional skill, should receive the punishment, which the law denounces ....23

Following such admonitions, early federal grand juries used their power of presentment both to accuse ${ }^{24}$ and to present grievances to the government. ${ }^{25}$

apparently overlooked these sources, one author implies, first, that Anti-Federalists did not voice concern about executive prosecutorial power and, second, that they failed to do so because they did not view it as an exclusively executive function. Stephanie A.J. Dangel, Note, Is Prosecution a Core Executive Function? Morrison v. Olson and the Framers' Intent, 99 YALE L.J. 1069, 1076-77 (1990). This simply is not the case. They openly feared prosecutorial power, attributed it to the executive branch, and found a check not in the legislative or judicial branches, but in the grand jury.

Several state conventions for ratification of the U.S. Constitution were concerned about the absence of grand jury protections. Massachusetts, New Hampshire, and New York proposed amendments requiring grand jury indictments. 2 THE BILL OF RIGHTS: A DOCUMENTARY HISTORY 677 (Massachusetts Ratifying Convention, 1788), 761 (New Hampshire Ratifying Convention, 1788), 855 (New York Ratifying Convention, 1788) (Bernard Schwartz ed., 1971). These three proposed amendments all mention only "indictment." Therefore, the addition of the word "presentment" in the Fifth Amendment appears to have been a deliberate effort to ensure that federal grand juries could wield this power.

21. David Katz has noted the importance of grand jury charges as guides to the Supreme Court Justices' views on various legal subjects, including constitutional law, since the Court's limited appellate review made it impossible for Justices to discuss many topics in any other official forum. David J. Katz, Grand Jury Charges Delivered by Supreme Court Justices Riding Circuit During the 1790's, 14 CARDOzo L. REV. 1045, 1046 n.3 (1993).

22. James Wilson, Charge to the Grand Jury of the Circuit Court for the District of Delaware (Apr. 27, 1790), reprinted in 2 DOCUMENTARY HISTORY, supra note 19, at 41 n.20; see also William Paterson, Charge to the Grand Jury of the Circuit Court for the District of Pennsylvania (May 4, 1795), reprinted in 3 DOCUMENTARY HISTORY, supra note 19, at 40 ("The due execution of the system of penal jurisprudence depends almost entirely upon the diligence and rectitude, the ability and firmness of grand juries. They must present before the court can punish. The proper exercise of their function protects the innocent, and brings forward the guilty for conviction and punishment ....").

23. 2 JAMES WILSON, WORKS OF JAMES WILSON 536 (Robert G. McCloskey ed., Harvard Univ. Press 1967) (1804).

24. See, e.g., Abstract of a Presentment of the Grand Jury of a Special Session of the Circuit Court for the District of Pennsylvania (July 22, 1793), reprinted in 2 DOCUMENTARY HISTORY, supra note 19, at 424 (presentment of various people for arming ships in the port of Philadelphia in violation of treaties 
Like their English and colonial predecessors, federal grand juries continued to present government officials; the most controversial presentment by a federal grand jury was an accusation against a U.S. Congressman. ${ }^{26}$

In the early years of the Republic, one government official suggested that a federal prosecutor had a duty to indict if the grand jury made a presentment. In 1794, Attorney General William Bradford gave an opinion on whether a district court had jurisdiction over an offense against a British consul ${ }^{27} \mathrm{He}$ and the district attorney thought that the offense did not fall within federal jurisdiction. But he advised the injured party to go directly before a federal grand jury: "[I]f the grand jury will take it upon themselves to present the offence in that court, it will be the duty of the district attorney to reduce that presentment into form, and the point in controversy will thus be put in a train for judicial determination." ${ }^{28}$ Bradford would therefore have placed initial

and presidential proclamation of neutrality).

25. This aspect of grand juries' activity links the institution strongly with the right to petition and with the other expressive rights of the First Amendment. See infra note 131 .

Federal grand juries in Georgia, for example, repeatedly recommended that Congress reform or repeal excise laws. See Presentments of the Grand Jury of the Circuit Court for the District of Georgia (Oct. 18, 1791; Apr. 27, 1792; Nov. 13, 1792), reprinted in 2 DOCUMENTARY HISTORY, supra note 19, at 224, 272, 332-33. The lack of a Bill of Rights was another frequent complaint. One grand jury declared: "We present the want of a Bill of rights clearly defining the reserved rights of the several States, comprehended in the Guarantee of a Republican form of Government to each state by the constitution of the United States...." Id. at 224. A federal grand jury in Virginia presented "as a national Grievanc[e] the recovery of . . . Debts by British Subjects until that Government shall fully comply with the treaty of peace on their part ...." Presentment of the Grand Jury of the Circuit Court for the District of Virginia (May 23, 1794), reprinted in 2 DOCUMENTARY HISTORY, supra note 19, at 472.

26. After a charge from Justice Iredell emphasizing the powers of the grand jury and the danger created by those who opposed the new government, a federal grand jury in Virginia presented Samuel J. Cabell, a Congressman from that commonwealth, for disseminating "unfounded calumnies" against the federal government in a letter to his constituents. Thomas Jefferson was quick to defend his Representative and declared that "Federalist judges had perverted grand juries from a legal to a political engine" by urging them "to become inquisitors on the freedom of speech." YOUNGER, supra note 10, at 50. For a defense of the grand jury's power, see "A Friend to Juries" to Samuel Jordan Cabell, VA. GAZETTE, \& GEN. ADVERTISER, June 30, 1797, reprinted in 3 DOCUMENTARY HISTORY, supra note 19, at 207, 209 ("In the liberty of their opinions and the subject of their presentments, juries have no other limitation than the observance of their oath. They are sworn to present every irregular and disorderly, as well as illegal and criminal act, that comes within their knowledge.").

Partisan rivalry also erupted in the late 1790's over grand jury proceedings concerning the Alien and Sedition Acts. Indeed, the Sedition Act (1798) itself resulted from confusion over whether federal grand juries could indict for common law crimes. See Judiciary Act of 1789, ch. 20, § 29, 1 Stat. 73, 88. Some Federalists felt that they could, but many others had doubts and insisted on the passage of legislation. United States v. Hudson \& Goodwin, 11 U.S. (7 Cranch) 32 (1812), finally resolved the issue by prohibiting the creation of federal common law crimes. See Gary D. Rowe, The Sound of Silence: United States v. Hudson \& Goodwin, the Jeffersonian Ascendancy, and the Abolition of Federal Common Law Crimes, 101 YALE L.J. 919 (1992); Ruth Wedgwood, The Revolutionary Martyrdom of Jonathan Robbins, 100 YALE L.J. 229, 242 n.33 (1990) (noting that before Hudson \& Goodwin, federal common law crimes were prosecuted under several different theories).

27. The problem of determining federal jurisdiction preoccupied the first U.S. Attorneys General. See Harold J. Krent, Executive Control over Criminal Law Enforcement: Some Lessons from History, 38 AM. U. L. REv. 275, 287 (1989). Bradford was willing to make the grand jury the sole gatekeeper of a major legal issue in the early Republic.

28. 1 Op. Att'y Gen. 22, 23 (1794). The consul alleged that a mob assembled in front of his house in Norfolk, Virginia insulted him with "improper language" and demanded that he deliver to them certain supposed residents there. 
determination regarding jurisdiction with the grand jury, not with the prosecutor.

Although Bradford saw prosecutorial discretion as limited, fifteen years later Chief Justice Marshall, sitting as a circuit judge, came to the opposite conclusion. Marshall declared that "[t]he usage of this country has been, to pass over, unnoticed, presentments on which the attorney does not think it proper to institute proceedings. ${ }^{29} \mathrm{He}$ went on to discuss the advantages of this custom in a system in which jurisdiction was not clearly established: "This usage is convenient, because it avoids the waste of time, which would often be consumed in the inquiry, whether the court could take jurisdiction of the offence presented. I am not disposed to disturb it, unless strong reasons should require my interposition. ${ }^{n 30} \mathrm{He}$ therefore left initial determination of a federal court's jurisdiction in a particular criminal matter not with the grand jury, but with the prosecutor, and upheld the traditional limits of the presentment power. Marshall's opinion came to be regarded as definitive. Although the grand jury could not force a prosecution, presentments remained potent; grand juries continued to make them, and they were widely publicized.

\section{Slow Decline}

From the mid-nineteenth century to the promulgation of the Federal Rules of Criminal Procedure in 1946, the power and independence of the federal grand jury steadily declined. Although courts periodically affirmed the grand jury's traditional powers, in practice these sank into disuse. As the number of federal prosecutors multiplied, these officials relied less on grand juries to bring charges of their own accord. As populations grew larger and more mobile, fewer jurors had intimate knowledge of a community's affairs. As the law grew more complex and investigative techniques improved, their lack of staff put grand juries at a greater disadvantage compared to prosecutors.

The grand jury endured fierce criticism in the mid-nineteenth century. ${ }^{31}$ Predictably, early attacks on the institution came from those who, like Bentham in England, mistrusted amateurs. ${ }^{32}$ American jurisdictions began to limit the grand jury's powers. ${ }^{33}$ In 1859 , Michigan became the first state to require that

29. United States v. Hill, 26 F. Cas. 315, 316 (C.C.D. Va. 1809) (No. 15,364).

30. 26 F. Cas. at 316.

31. Younger traces in detail the grand jury's decline in the nineteenth century. YouNGER, supra note 10, 56-71, 134-54.

32. Bentham condemned the grand jury as a "a miscellaneous company of men" and declared that a legally trained prosecutor could screen accusations more efficiently. JEREMY BENTHAM, THE ELEMENTS OF THE ART OF PACKING, AS APPLIED TO SPECIAL JURIES 14-28 (London, E. Wilson 1821).

33. See Fourth REPORT OF THE NEW YoRK COMMISSIONERS ON PRACTICE AND PleAdings (Code of Criminal Procedure) xxxvii (1849) (criticizing grand juries' arbitrariness and recommending compulsory 
all crimes be prosecuted on the information of a district attorney. ${ }^{34}$ After the Civil War, the movement gathered speed. Commentators castigated grand jurors for being "utterly ignorant both of law and the rules of evidence"35 and "irresponsible."36 Critics blasted the grand jury's "secret methods"37 and claimed that grand jury protection, while useful under a despotism, served no purpose in a democracy. ${ }^{38}$ Professional prosecutors, it was argued, could screen accusations better, faster, and cheaper. ${ }^{39}$

Mid-nineteenth-century Supreme Court Justices adopted varying attitudes toward grand juries and their presentment power. Chief Justice Taney was among the first to be dismissive of grand juries. In an 1836 charge to a grand jury in which he announced he saw little reason to bother delivering a charge at all, ${ }^{40}$ Taney espoused a narrow view of the presentment power: "You will ... present no one, unless ... the evidence before you is sufficient, in the absence of any other proof, to justify the conviction of the party accused."41 In 1868 Chief Justice Chase, on the other hand, emphasized the grand jury's duty "to leave no one unpresented from fear, favor, and affection."42 A few years later Justice Field downplayed presentments, claiming that professional prosecutors had rendered them obsolete. ${ }^{43}$

Despite these differing beliefs, at the end of the century ${ }^{44}$ the Supreme

examination of an accused by a magistrate before presentment or indictment).

34. YOUNGER, supra note 10 , at 69.

35. Eugene Stevenson, Our Grand Jury System, 8 CRIM. L. MAG. 713-14 (1886).

36. Francis Wharton, A TREATISE ON CRIMINal Pleading AND PRACTICE 227 (Philadelphia, Kay \& Brother, 9th ed. 1889).

37. YouNGER, supra note 10 , at 143.

38. George Lawyer, Should the Grand Jury System Be Abolished?, in 29 REPORT N.Y. STATE BAR Ass'N 29-43 (1906).

39. Justice Henry B. Brown, Address by Justice Brown (July 1892), in 13 ProceEdings Ohio STATE BAR ASS'N $42-43$ (1892).

40. Charge to Grand Jury, 30 F. Cas. 998, 998 (C.C.D. Md. 1836) (No. 18,257). Taney felt that charges had once been "necessary for the purposes of justice" but were no longer: "[F]ew, I trust, if any, infractions of the law are likely to come before you, and it would be a waste of time in the court to engage itself in discussing principles, and enlarging upon topics which are not to lead to any practical result ....." Id. at 998-99. Taney's views were a far cry from those of Justice Wilson. See supra notes 22-23 and accompanying text.

41. Id. at 999 .

42. Charge to Grand Jury, 30 F. Cas. 980, 980 (C.C.D. W. Va. 1868) (No. 18,248). Chase was particularly concemed that the grand jury exercise its power to examine public officials: "You may, and you should, summon before you officers of the government, and others whom you have reason to believe possess information proper for your action, and examine them fully." Id.

43. Charge to Grand Jury, 30 F. Cas. 992, 996 (C.C.D. Cal. 1872) (No. 18,255) ("This form of accusation [presentment] has fallen in disuse since the practice has prevailed-and the practice now obtains generally-for the prosecuting officer to attend the grand jury and advise them in their investigations."). Field was the brother of the codifier David Dudley Field, who had tried to abolish the grand jury in New York; both brothers were great believers in experts. See YouNGER, supra note 10, at 140. Although Justice Field knew of Chief Justice Chase's charge (he quoted directly from it at length), he was anxious to prevent grand juries from examining public officials. After stating that California state grand juries had general powers to examine state officials, Field warned: "No such general authority to inspect the books of the officers of the United States, and to subject the officers themselves to examination in respect to the entries in those books, is possessed by the grand juries of the national courts." $30 \mathrm{~F}$. Cas. at 994.

44. In the late nineteenth century, state grand juries played a valuable role in ferreting out public comuption. Grand juries made dramatic charges against corrupt city officials in New York (involving the 
Court offered vague praise for the grand jury's traditional powers. In 1895 , Justice Brewer in Frisbie v. United States described a system relying on an energetic grand jury: "[I]n this country the common practice is for the grand jury to investigate any alleged crime, no matter how or by whom suggested to them, and after determining that the evidence is sufficient to justify putting the party suspected on trial, to direct the preparation of the formal charge or indictment." ${ }^{25}$ The prosecutor was not to dominate grand jurors. The Court stressed the historical basis for the grand jury's presentment power in Hale $v$. Henkel. ${ }^{46}$ After quoting a Maryland opinion holding that "'grand juries . . . may lawfully themselves, and upon their own motion, originate charges against offenders though no preliminary proceedings have been had before a magistrate, and though neither the court nor the state's attorney has laid the matter before them," J47 Justice Brown declared that "[ $t]$ he rulings of the inferior Federal courts are to the same effect." ${ }^{\text {48 }}$ In 1919, the Court announced that " $t]$ he Fifth Amendment and the statutes relative to the organization of grand juries recognize such a jury as being possessed of the same powers that pertained to its British prototype."49 The Court held that the grand jury predated the Constitution and was preserved by that document with all its common law powers. ${ }^{50}$

Tammany Hall scandal) and elsewhere. Wright, supra note 3, at 473.

45. 157 U.S. 160,163 (1895).

46. 201 U.S. 43, 59-64 (1906). The waning of the presentment power is evident in Justice Brown's comment that by this time presentments were "usually made, as in this case, for an offense committed in the presence of the jury." Id. at 59. Indeed, in 1912 the Eighth Circuit mistakenly defined a presentment as "an accusation made by grand jurors upon personal knowledge or observation of the facts instead of upon the testimony of witnesses." McKinney v. United States, 199 F. 25, 28 (8th Cir. 1912). That the court defined the term "presentment" at all, let alone defined it incorrectly, suggests that the power had fallen out of regular use.

47. Id. at 63 (quoting Blaney v. Maryland, 74 Md. 153, 156 (1891)).

48. Id. at 63. Hale v. Henkel involved both of the situations in which presentments are still regularly used: contempt for failing to obey a grand jury subpoena and contempt for failing to answer questions before a grand jury. The Court noted that "presentments have largely fallen into disuse in this country" but nonetheless still existed. Id. at 61.

49. Blair v. United States, 250 U.S. 273, 282 (1919).

50. Id.; see also United States v. Thompson, 251 U.S. 407, 413 (1920) ("[T]he power and duty of the grand jury to investigate is original and complete, susceptible of being exercised upon its own motion and upon such knowledge as it may derive from any source which it may deem proper, and is not therefore dependent for its exertion upon the approval or disapproval of the court . ...").

Ex-jurors also acted to protect the grand jury's powers; they formed associations. The Grand Juror's Association of New York was founded in 1912, and in 1924 began publishing The Panel, a pro-grand jury periodical. Chicagoans founded the Grand Juror's Federation of America in 1931, and many other localities followed. YOUNGER, supra note 10 , at 228,231 . These associations combatted a slew of studies that criticized the grand jury. For examples of such studies, see AMERICAN LAW INST., CODE OF CRIMINAL PROCEDURE \$\$ 113-114 (1928); REPORT ON NATIONAL PROSECUTION OF THE NATIONAL COMMISSION ON LAW OBSERVANCE AND ENFORCEMENT 34, 124 (1931) (the "Wickersham Commission" report); RAYMOND Moley, PoltTics and CRiminal Prosecution 127-28 (1929); Raymond Fosdick et al., Criminal JUSTICE IN CLEvelAND 211-12, 248 (Roscoe Pound \& Felix Frankfurter eds., 1922). The fierce criticism is odd in light of the grand jury's triumphs in combatting municipal corruption in the 1920's and 1930's, most spectacularly in New York collaborating with special prosecutor Thomas E. Dewey. (The grand jury had demanded a special prosecutor.) YouNGER, supra note 10, at 235. 
Notwithstanding these general affirmations of grand jury powers, permanent officials continued to gain the upper hand during the early twentieth century. In 1932, two authors dismissed presentments: "[Presentments] may be regarded simply as instructions for indictments, for the framing of the latter normally follows. However, since public prosecutors are, under our practice, available to the grand jury for the drawing up of bills of indictment, the presentment form is practically obsolete." possibility that the prosecutor and the grand jury might disagree. This forgetfulness of the presentment's significance foreshadows the approach taken in the Federal Rules of Criminal Procedure.

\section{Modern Federal Grand Juries}

For all practical purposes, the Federal Rules of Criminal Procedure have abolished the grand jury's presentment power. The grand jury secrecy provisions are so strict that a court may seal a presentment. Since the main function of a presentment, now that a comprehensive network of prosecutors exists, is to publicize wrongdoing, such judicial discretion guts the power. Confusion arises because the Rules smother the presentment power without doing so explicitly. The Rules conflict with traditional federal practice, and, because the Supreme Court has offered no guidance, lower courts have floundered in trying to discern (or make) the law.

Burying the presentment power is not unconstitutional because the accused is still protected by the indictment requirement. But loss of this power means that prosecutorial discretion goes uncriticized, and citizens are not encouraged to participate more actively in the workings of government.

\section{The Federal Rules of Criminal Procedure}

The Rules, which took effect in 1946, allegedly codified the existing common law practice respecting grand juries. But the Rules essentially subject the presentment power to the discretion of the court. Rule 6(e)(3), relating to grand jury secrecy, places great discretion in the hands of the judge and the government prosecutor. ${ }^{52}$ According to the Rules, the grand jury cannot make

51. George H. Dession \& Isadore H. Cohen, The Inquisitorial Functions of Grand Juries, 41 YALE L.J. 687, 705-06 (1932) (footnote omitted).

52. Rule $6(\mathrm{e})(3)$ provides the following exceptions to the general requirement of secrecy:

(A) Disclosure otherwise prohibited by this rule of matters occurring before the grand jury, other than its deliberations and the vote of any grand juror, may be made to -

(i) an attorney for the government for use in the performance of such attorney's duty; and

(ii) such government personnel . . . as are deemed necessary by an attorney for the government to assist an attorney for the government in the performance of such attorney's duty to enforce federal criminal law.

$\cdots$ 
any disclosure, including a presentment, without court permission. At common law, no such permission was necessary. Yet the advisory committee's notes to the rule declare that it "continues the traditional practice of secrecy on the part of members of the grand jury .... .53 Rule 7, which governs indictment and information, makes no provision for presentments. The historical notes to the rule state: "Presentment is not included as an additional type of formal accusation, since presentments as a method of instituting prosecutions are obsolete, at least as concerns the Federal courts." ${ }^{\text {54 }}$ As noted above, presentments had not fallen entirely out of use..$^{55}$

When the Rules went into effect, legal scholars proclaimed that, with a few minor exceptions, they embodied the common law. Several authors stated that the secrecy rules were entirely customary: "The policy of secrecy is traditional, and violation of the required . . oath . . . is both a contempt and a crime at common law." 56

Courts were slow to apply Rule 6(e) to the presentment power. In part, this was because secrecy provisions traditionally were not applied to presentments. Also, because of congressional praise for the grand jury's potential to investigate organized crime, judges were probably somewhat reluctant to limit grand jury powers during the 1950 's. But gradually, as cases arose in which grand juries made questionable presentments, federal courts responded by severely restricting the power.

(C) Disclosure otherwise prohibited by this rule of matters occurring before the grand jury may also be made -

(i) when so directed by a court preliminarily to or in connection with a judicial proceeding;

(ii) when permitted by a court at the request of the defendant, upon a showing that grounds may

exist for a motion to dismiss the indictment because of matters occurring before the grand jury;

(iii) when the disclosure is made by an attorney for the government to another federal grand

jury; or

(iv) when permitted by a court at the request of an attorney for the government, upon a showing that such matters may disclose a violation of state criminal law, to an appropriate official of a state or subdivision of a state for the purpose of enforcing such law.

FED. R. CRIM. P. 6(e)(3) (emphasis added).

53. FED. R. CRIM. P. 6 advisory committee's note.

54. FED. R. CRIM. P. 7 advisory committee's note; see ChARLes A. WRIGHT, Federal PRACTICE AND PROCEDURE $\$ 121$, at 338 (1982) (relying on this note for proposition that presentments are obsolete in federal courts).

55. See supra text accompanying notes 44-50. The District of Columbia not only allowed presentments, but until 1969 they were the primary form of grand jury accusation. See Gaither v. United States, 413 F.2d 1061, 1065 (D.C. Cir. 1969) (opinion by Judge Skelly Wright striking down presentment procedure and requiring resubmission of indictment to full grand jury); infra note 72 .

56. George H. Dession, The New Federal Rules of Criminal Procedure (pt. 2), 56 YALE L.J. 197, 203 n.97 (1947); see also George H. Dession, The New Federal Rules of Criminal Procedure (pt. 1), 55 YALE L.J. 699 (1946); Lester B. Orfield, The Federal Rules of Criminal Procedure, 33 CAL. L. REV. 543, 549 (1945). Some commentators were more honest:

In fact, confusion reigns as to just what a [federal] grand jury can do. Federal statutes are silent on the relationship which is to exist between a federal grand jury, the district court which summons it, and the United States attorney's office in the district. From 1789 to the present, Congress has made no definitive statement concerning grand jury powers.

Comment, Powers of Federal Grand Juries, 4 STAN. L. REV. 68, 68 (1951) (footnote omitted). 


\section{Praise for the Grand Jury in the 1950's}

During the 1950's, courts and congressional reports emphasized the grand jury's common law powers, particularly as a means of combatting organized crime. A federal district court in California declared in dicta in an organized crime case that a grand jury "may have a presentment contrary to the direct orders of a judge."57 Supreme Court opinions also extolled traditional grand jury powers. ${ }^{58}$ Congress was similarly impressed. The famous Kefauver Reports on organized crime laid great stress on the grand jury's crime-fighting abilities. ${ }^{59}$ Then-Senator Nixon wanted to increase the power of federal grand juries to make them the primary weapon against organized crime. The same day the Kefauver Committee issued its final report, Nixon introduced a bill to define and enlarge federal grand jury powers. ${ }^{60}$

\section{Problems with Grand Jury Presentments}

The early 1950's brought a concern not only about organized crime, but also about un-American activities. Investigations of the former enhanced the grand jury's reputation, but investigations of the latter damaged it. During the

57. United States v. Smyth, 104 F. Supp. 283, 293 (N.D. Cal. 1952). The judge believed that the Federal Rules of Criminal Procedure "restate[d] in general the practice of the United States courts," and he did not accord them nearly the importance of Supreme Court opinions: "[T]he authoritative pronouncements binding upon the federal court in adapting the historical common law grand jury to conditions in this country are found in a series of opinions of the Supreme Court of the United States." Id. at $283 \mathrm{n} .2$. The judge noted the "prevalent confusion and doubt in the lay mind and even in the minds of lawyers" as to the powers of the grand jury. He therefore decided to give "a clear and decisive statement of the powers and duties of the grand jury," which would provide "a definite guide for the future." Id. at 287 (footnote omitted). Sinyth concerned the legality of communications to the grand jury in an organized crime case, and Judge Fee strongly emphasized the grand jury's effectiveness in battling organized crime and corruption among public officials. Id. at 290.

58. "The grand jury is an English institution, brought to this country by the early colonists and incorporated in the Constitution by the Founders. There is every reason to believe that our constitutional grand jury was intended to operate substantially like its English progenitor." Costello v. United States, 350 U.S. 359, 362 (1956) (holding that indictment based solely on hearsay evidence does not violate Fifth Amendment). Justice Black also extolled the grand jury's traditional powers: "And in this country as in England of old the grand jury has convened as a body of laymen, free from technical rules, acting in secret, pledged to indict no one because of prejudice and to free no one because of special favor." Id.

59. THIRD INTERIM REPORT OF THE SPECIAL COMM. TO INVESTIGATE ORganized CRIME IN INTERSTATE COMMERCE, S. REP. No. 307, 82d Cong., 1st Sess. 3 (1951) (warning Americans not to rely on central government to fight organized crime, but to use local grand juries to combat it).

60. S. 2086, 82d Cong., 1st Sess. (1951); see infra note 139 and accompanying text. The bill died an obscure death in the Judiciary Committee, see United States v. Cox, 342 F.2d 167, 186 n.4 (Wisdom, J., concurring specially), and has not been discussed by recent commentators. It is possible that Nixon's respect for grand juries was nourished by the grand jury investigation and eventual indictment of Alger Hiss. At the time of Hiss's indictment, Nixon, a first-term Representative from California on the House Committee on Un-American Activities (HUAC), was making a name for himself as a vigorous investigator. The grand jury managed to examine several important witnesses whom HUAC had tried unsuccessfully to obtain. Allen WeinsteIn, PeruuRY: The Hiss-Chambers CASE 280 (1978). Nixon was delighted with the indictment, claiming that "Mr. Truman is on the hook" regarding the President's earlier disapproval of the HUAC investigation. The Committee viewed Hiss's indictment as a "vindication" of its inquiries and "publicly congratulated" the grand jury. Id. at 301. 
civil rights movement in the 1960 's, courts grew increasingly wary of amateur citizen bodies not under the direct control of the central government. Judges began to use Rule 6(e) to restrict the presentment power. Cases in these areas suggest some of the problems with grand jury discretion. The reforms suggested in Part III, especially those limiting presentments to government officials and contractors and providing for declaratory judgment, would resolve these difficulties.

In 1953, a federal district court in Manhattan faced a situation in which a grand jury and prosecutor had colluded to deny the accused the ability to be heard by issuing a presentment. ${ }^{61}$ The court granted a motion to expunge a grand jury presentment accusing thirteen unnamed union leaders of perjury for having filed non-Communist affidavits required by the Taft-Hartley Act. The union leaders made the unopposed claim that the grand jury foreman, the Special Assistant to the Attorney General, and the U.S. Attorney for the district had leaked the thirteen names to the press, ${ }^{62}$ which suggests that the grand jury and the prosecutor were actually in agreement and wanted to make public a criminal charge without the trouble of prosecuting. The court claimed that the presentment "deprived [the union leaders] of the right to defend themselves and to have their day in a Court of Justice - their absolute right had the Grand Jury returned an indictment." ${ }^{63}$ The court stated that the grand jurors had violated Rule 6(e), which, it claimed, implemented the grand jury's traditional "ancient oath" of secrecy. ${ }^{64}$

In United States v. Cox, ${ }^{65}$ the Fifth Circuit was confronted with a grand jury and a district court who wanted to force a questionable prosecution over the objections of the prosecutor. The multiplicity of opinions in that case (there were four) illustrates the muddled state of grand jury law. The case involved a petition by the Acting Attorney General to invalidate a district court order requiring a U.S. Attorney to draft and sign an indictment according to the grand jury's wishes. The plurality opinion held that the U.S. Attorney could not be required to sign an indictment and thereby initiate a prosecution. ${ }^{66}$ The other opinions proposed a wide range of solutions, ${ }^{67}$ but all except that of

61. Application of United Elec., Radio \& Mach. Workers, 111 F. Supp. 858 (S.D.N.Y. 1953).

62. Id. at 861 .

63. Id. Of course, the accused does not have an "absolute right" to a day in court after an indictment; federal prosecutors (and the courts, in cases of unnecessary delay) have the power to dismiss an indictment. FED. R. CRIM. P. 48. Still, the concern that the accused lacks an opportunity to answer a presentment is valid.

64. 111 F. Supp. at 865-66. The opinion also cited the advisory committee's notes declaring that presentments were obsolete. Id. at $863 \mathrm{n}$.13. Throughout the opinion, the court put the word "presentment" in quotation marks, an odd convention to adopt regarding a procedure legitimized by the Constitution (which the court never quoted).

65. 342 F.2d 167 (5th Cir. 1965). The grand jury wanted to indict two black men for perjury after they testified in a suit against the Registrar of Clarke County, Mississippi and the State of Mississippi to enforce voting rights under the Fourteenth Amendment and the Civil Rights Act. Id. at 193-96.

66. Id. at 172 (Jones, J., plurality opinion).

67. The two judges who signed the plurality opinion simply held that the U.S. Attorney could not be 
Judge Wisdom ignored the possibility of a presentment. ${ }^{68}$ Judge Wisdom, in a thoroughly researched concurrence, noted that " $[c]$ riminal presentment . . . may be in disuse in federal courts, but it has not been read out of the Constitution." ${ }^{, 69} \mathrm{He}$ recommended a presentment in that case, stating: "This use of presentment would be in accord with the established procedure in the common law and with the original understanding of the framers."70

Despite Judge Wisdom's views, within a few years the D.C. Circuit eradicated presentments in Gaither $v$. United States. ${ }^{71}$ As Judge Skelly Wright noted in the opinion, a presentment was the "normal procedure" followed in the District of Columbia for initiating a prosecution. ${ }^{72}$ In Gaither, the grand jury made a presentment of the two defendants for grand larceny, without any further detail. Afterward the prosecutor drew up an indictment, alleging specific facts, and the grand jury foreman reviewed and signed the document. The court rejected the contention that the translation of the presentment into an indictment was a mere clerical procedure, since "[n]one of the essential substantive elements of an indictment [were] shown" in the presentment. It held that the indictment should have been submitted to the entire grand jury for approval. ${ }^{73}$ However, the court acknowledged that "[t]his contention might have some merit if the jurors had voted on some set of factual charges which made up the substance of an indictment, and the prosecutor had reduced it to final form by improving the punctuation or phrasing." ${ }^{.74}$ Despite this seeming

forced to sign the indictment, $i d$. at 172 (Jones, J., joined by Tuttle, J.); three concluded that he could be forced to draft and sign an indictment, id. at 181 (Rives, Gewin, \& Bell, JJ., concurring in part and dissenting in part); one believed that he could not be forced to sign but could be forced to draft an indictment, id. at 182 (Brown, J., concurring specially); one thought that the grand jury could make a presentment in open court that the prosecutor was free to ignore, id. at 196 (Wisdom, J., concurring specially).

68. The plurality opinion explicitly stated: "Nothing in this case involves or requires a discussion of a presentment." Id. at 170 n.2 (Jones, J., plurality opinion).

69. Id. at 188 (Wisdom, J., concurring specially).

70. Id. at 189 (Wisdom, J., concurring specially). Judge Wisdom continued: "I consider it preferable to the placebo the Government suggests: an indictment (which is not an indictment) to lie fallow until some day another Attorney General might or might not come along to vitalize it." Id. The judge erred in this last statement. In fact, a prosecutor could "vitalize" a presentment and transform it into an indictment without further grand jury participation. As the Fifth Amendment states, the accused could be held to trial after either a presentment or an indictment. U.S. CONST. amend. V.

A federal district court judge in Maryland cited Judge Wisdom's opinion in Cox in deciding to allow disclosure of most of a grand jury presentment. In re Presentment of Special Grand Jury Impaneled January, 1969, 315 F. Supp. 662, 676 (D. Md. 1970). The court, however, emphasized that it was not attempting "to lay down a rule which should apply in all situations." Id. at 678 . The judge mentioned two factors that led to a ruling for disclosure in the particular case: the media had disclosed the names of the people who had been investigated, and rumors in the press suggested that certain people had been investigated who in fact had not been. Id.

71. 413 F.2d 1061, 1061 (D.C. Cir. 1969).

72. Id. at 1065; see also United States v. Elliott, 25 F. Cas. 1003, 1003 (Crim. Ct. D.C. 1845) (No. 15,045 ) (stating that because of colonial Maryland statute, practice had developed in District of Columbia "to precede [all] indictments by presentment. . . [A] presentment of crime, or the reverse, under the peculiar practice here, is and ought to be equivalent to the action and judgment of a grand jury upon a bill of indictment.").

73. 413 F.2d at 1070.

74. Id. 
acknowledgement that a presentment might satisfy the Fifth Amendment under different circumstances, the court proceeded to deny that the procedure could ever be valid: "Indeed, it has been clear since the adoption of the Federal Rules of Criminal Procedure that a presentment is not a sufficient substitute for an indictment found by 12 grand jurors." 75

\section{Congress Considers Reform}

During the 1970's, while the presentment power continued to fade, ${ }^{76}$ Congress actively explored grand jury reform. ${ }^{77}$ The 95th Congress considered several reform bills, including four different constitutional amendments to alter or abolish the Fifth Amendment grand jury requirement. ${ }^{78}$ In 1983, Congress amended the rule to clarify aspects of grand jury secrecy. ${ }^{79}$ Most significantly, the 1983 amendments provided for sealing grand jury records. ${ }^{80}$ The court's power to seal such records became

75. Id. at 1074 n.38; see United States v. Coachman, 752 F.2d 685, 689 n.23 (D.C. Cir. 1985) (citing Gaither for proposition in dicta that presentments are obsolete in federal system).

76. During the 1970's, the confusion surrounding grand jury law led to peculiar results. Because of grand jurors' ignorance of their powers, they sometimes issued indictments accusing unindicted people of criminal offenses. In 1975, the Fifth Circuit affirmed expunging references to people named as unindicted coconspirators in a grand jury indictment. United States v. Briggs, 514 F.2d 794, 802 (5th Cir. 1975); $c f$. Note, supra note 4, at 672 "When the grand jury, desiring to indict an individual, accedes to the prosecutor's request to name the individual an unindicted coconspirator, both the historical presentment power of the grand jury and the public's interest in the faithful execution of the laws by the Executive combine to mitigate the due process considerations.").

77. At least in part, this interest in grand jury reform was prompted by the alleged misuse of grand juries during President Nixon's administration. See Peter Arenella, Reforming the Federal Grand Jury and the State Preliminary Hearing To Prevent Conviction Without Adjudication, 78 MiCH. L. REV. 463 (1980); Thomas P. Sullivan \& Robert D. Nachman, If It Ain't Broke, Don't Fix It: Why the Grand Jury's Accusatory Function Should Not Be Changed, 75 J. CRIM. L. \& CRIMINology 1047, 1049 n.11 (1984); Michael E. Deutsch, The Improper Use of the Federal Grand Jury: An Instrument for the Internment of Political Activists, 75 J. CRIM. L. \& CRIMINOLOGY 1159, 1179-83 (1984).

78. See Grand Jury Reform: Hearings on H.R. 94 Before the Subcomm. on Immigration, Citizenship, and International Law of the House Comm. on the Judiciary, 95th Cong., 1st Sess. 484 (1977); The Grand Jury Reform Act of 1978: Hearings on S. 3405 Before the Subcomm. on Administrative Practice and Procedure of the Senate Comm. on the Judiciary, 95th Cong., 2d Sess. 154 (1978); Sullivan \& Nachman, supra note 77, at 1047 \& n.1. The 1970's academic debate was vigorous; Judge Campbell joined the fray with an especially influential piece. William J. Campbell, Eliminate the Grand Jury, 64 J. CRIM. L. \& CRIMINOLOGY 174 (1973).

Amendments to Rule 6(e) in 1977 facilitated disclosure of grand jury materials to investigators other than lawyers. See Janice S. Peterson, Comment, Criminal Procedure-Federal Rule of Criminal Procedure 6(e): Criminal or Civil Contempt for Violations of Grand Jury Secrecy? 12 W. NEW ENG. L. REV. 245, 261-65 (1990) (giving a thorough description of the amendments' legislative history). In 1979, Congress amended Rule 6 to require recording of all grand jury proceedings except jurors' deliberations and voting. Order Amending Fed. R. Crim. P. 6, 441 U.S. 985, 989-90 (1979). This requirement creates a record on which a declaratory judgment action may be based. See infra text accompanying note 133 .

79. Order Amending Fed. R. Crim. P. 6, 461 U.S. 1117, 1121-22 (1983).

80. "Records, orders, and subpoenas relating to grand jury proceedings shall be kept under seal to the extent and for such time as is necessary to prevent disclosure of matters occurring before a grand jury." FED. R. CRIM. P. 6(e)(6). The provision was a response to a report of the Comptroller General observing that various federal districts had been following diverse practices in handling court documents related to grand jury proceedings. See 2 SARA S. BEALE \& WILLIAM C. BRYSON, GRAND JURY LAW AND PRACTICE $\S 7: 03$ n.16 (1986). The 1983 amendments also clarified grand jury discharge, stating: "A grand jury shall 
significant in the Rocky Flats case, in which Chief Judge Finesilver sealed documents the grand jury had drafted.

The cases and statutory changes discussed above illustrate the confusion surrounding modern grand jury law. The Rules proclaimed themselves to be merely a codification of the common law when in fact they eliminated a traditional grand jury power; lower court judges have split on the question of allowing presentments; the Supreme Court has supported retention of traditional grand jury powers in vague terms; and Congress has tinkered with grand jury powers, never directly addressing the presentment issue.

\section{THE ROCKY FLATS CONTROVERSY}

The Rocky Flats case exemplifies the confusion in federal grand jury law. The law frustrates grand jurors, who are forbidden to exercise their traditional function of pointing out government wrongdoing. Interestingly, press accounts of the controversy never mention the word "presentment," so thoroughly has that grand jury power been forgotten. The time has come to revive it.

\section{A. The Facts}

In August 1989, Chief Judge Sherman G. Finesilver of the U.S. District Court for the District of Colorado called a special grand jury to investigate alleged environmental crimes at a Rockwell International plant in a Denver suburb. Located on land owned by DOE, the plant manufactured plutonium triggers for nuclear weapons under contract to the Department. Toward the end of the two-and-a-half-year investigation, the grand jurors became frustrated with the decision of the lead prosecutor, U.S. Attorney Michael J. Norton, not to indict individual officials of Rockwell or DOE. The grand jury rejected the proposed indictment of the corporation only. Norton then issued a criminal information and arranged a plea agreement in which Rockwell pled guilty to five felonies and five misdemeanors and paid an $\$ 18.5$ million fine. ${ }^{81}$ The grand jury's investigation was concluded as far as the prosecutor was concerned. ${ }^{82}$

The grand jurors were spurred to further action. With the help of a prosecutor's manual, they drafted "indictments" against five Rockwell employees and three DOE officials. They also submitted documents they called

serve until discharged by the court, but no grand jury may serve more than 18 months unless the court extends the service of the grand jury for a period of six months or less upon a determination that such extension is in the public interest." FED. R. CRIM. P. 6(g); see infra Part III.D.

81. Matthew L. Wald, Grand Jury Seeks Inquiry on Weapons Plant Case, N.Y. TIMES, Nov. 19, 1992, at A16.

82. Sharon LaFraniere, The Grand Jury that Couldn't: Frustrated by Rocky Flats Prosecutor, Panel Tried Mutiny, WASH. POST, Nov. 10, 1992, at A1. 
"presentments" and a report criticizing prosecutors' handling of the case. Chief Judge Finesilver sealed all these documents. Still not to be outdone, the jurors leaked information to the press. Harper's Magazine and Westword, a local Denver paper, published accounts of the grand jury proceedings. ${ }^{83}$ On October 16, 1950, Chief Judge Finesilver wrote an open letter to Norton asking the Justice Department to investigate the jurors for violations of their secrecy oath. Alarmed at the prospect of being investigated themselves, twelve jurors wrote to then-President-elect Clinton on November 18 requesting appointment of a special prosecutor to investigate the Justice Department's handling of the case. ${ }^{84}$ The jury foreman and another juror appeared on the steps of the U.S. Courthouse in Denver to give interviews to the press, generating national publicity. Norton responded, "Prosecutorial discretion is the obligation of the prosecutor and not the grand jury." ${ }^{85}$ Citing secrecy obligations, neither the jurors nor Norton went into details.

In November 1992, the grand jurors also took the unusual, if not unique, step of hiring a lawyer. ${ }^{86}$ In December, Chief Judge Finesilver denied a motion by media companies to release the documents the grand jury had drafted. $^{87}$ In October 1993, the Justice Department finally called off its investigation into the jurors' conduct. $^{88}$

83. Matthew L. Wald, Prosecutor Says Jurors Erred in Arms-Plant Case, N.Y. TIMES, Jan. 28, 1993, at $\mathrm{A} 13$.

84. Wald, supra note 81.

85. Id. (quoting Michael J. Norton). Norton decided that individuals should not be held accountable because of a "culture of laxity" at DOE. An Angry Jury Deserves a Hearing, N.X. TIMES, Dec. 1, 1992, at $\mathrm{A} 24$ (editorial).

86. Jonathan Turley, a law professor and head of the Environmental Crimes Project at George Washington University's National Law Center, has represented twenty-two of the grand jurors on a pro bono basis. Andrea Sachs, Rebellious Grand Jurors Hire Lawyer, A.B.A. J., Feb. 1993, at 31; Matt Siegel, Counseling the Renegade Rocky Flats Grand Jury, AM. LAw., Mar. 1993, at 110. Turley has been nothing if not a zealous advocate. In March, he complained to members of Congress and to the Department of Justice that Norton violated Rule 6 in a speech to the University of Denver Law School Federalist Society. "'In the very least, Mr. Norton's speaking engagements raise the question of a double standard applied to the grand jurors as opposed to the standard governing the Department of Justice itself,"' he said. Kelly Richmond, Norton May Have Violated Secrecy Law, Jurors' Attorney Charges, States News Serv., Mar. 8, 1993, available in LEXIS, Nexis Library, SNS File. Turley has also churned out newspaper editorials supporting his clients. See, e.g., Jonathan Turley, Who Controls Justice, Citizens or Government?, HoustoN CHRON., Oct. 11, 1993, at A17; Turley, The Government Versus the Grand Jury, CHI. TRIB., Sept. 23, 1993, at 23; Turley, Free the Rocky Flats 23, WASH. POST, Aug. 11, 1993, at A19.

87. In re Grand Jury Proceedings, Special Grand Jury 89-2 (Rocky Flats Grand Jury), 813 F. Supp. 1451,1451 (D. Colo. 1992). The judge held that presentments are obsolete in the federal system and treated the "indictments" and presentments as a report. Id. at 1462-63. He then determined that the documents did not meet the standard for submitting a report under 18 U.S.C. $\$ 3333(\mathrm{a})$ (1988). Id. at 1461.

In January 1993, Chief Judge Finesilver allowed a redacted version of the report to be made public. In re Grand Jury Proceedings, Special Grand Jury 89-2 (Rocky Flats Grand Jury), Civ. A. No. 92-Y-180, 1993 WL 245557 (D. Colo. Jan. 26, 1993). He refused to release the entire report because it "accused individuals identifiable by name or position ....; dealt in rumor and conjecture; engaged in social and even legal argument; dealt with political and social issues outside the province of the special grand jury's duty of investigating crime; contained charges not based upon a preponderance of the evidence; and followed a serious breach of grand jury secrecy." Id. at *1. Cf. supra notes $25,26$.

88. Let's Hear the Rocky Flats Jurors, N.Y. TIMES, Nov. 1, 1993, at A18 (editorial). The editorial called for the court to give permission for the jurors to testify in congressional hearings. 
Congress also leapt into the Rocky Flats fray with an investigation by the Investigations and Oversight Subcommittee of the House Committee on Science, Space, and Technology. ${ }^{89}$ The resulting report recommends that Congress grant the grand jurors immunity to enable them to testify before a full committee hearing. ${ }^{90}$ The grand jurors' lawyer tried to obtain immunity for his clients in time to allow them to testify before the Subcommittee, and the Subcommittee's suggestion shows that his efforts were not entirely fruitless. ${ }^{91}$ Congress has never before granted immunity to grand jurors, ${ }^{92}$ for the simple reason that grand jurors used to be automatically immune from prosecution for performing their traditional functions: issuing indictments, presentments, and reports. ${ }^{93}$ Requiring grand jurors to testify before a congressional committee could become an unwarranted interference with the grand jury's work. ${ }^{94}$

89. The Subcommittee's January report blasted the Justice Department for "extreme conservatism and lack of aggressiveness" in prosecuting the case and in blocking the grand jury report. Matthew L. Wald, Lawmakers Call Bomb Plant Too Lenient, N.Y. TIMES, Jan. 5, 1993, at A9. The impartiality of the Subcommittee's report is open to question, particularly in light of the circumstances of the subcommittee chairman. The New York Times described the report as "a parting shot at the top echelon of the Justice Department" by the chairman, Howard Wolpe (D-Mich.), who retired on January 5, 1993. Id. The report claims that DOE lobbied the Justice Department to "go easy" on Rockwell to prevent civil suits against the company by its neighbors. Among other instances, the Deputy Secretary of Energy, Henson Moore, was alleged to have lobbied the Justice Department during the plea negotiations to allow Rockwell to plead nolo contendere instead of guilty. Id. The report further alleges that superiors in Washington restrained Norton and an Assistant U.S. Attomey from prosecuting the case more vigorously. Neil Cartusciello, head of the Environmental Crimes Section at the Justice Department, has called the Subcommittee's claim "'flatly untrue" "and "reckless and irresponsible." Id.

90. Rudy Abramson, Justice Department Blasted for Curbs on Nuclear Plant Report, L.A. TIMES, Jan. 5,1993 , at A15.

91. At the request of the Subcommittee, Turley interviewed more than a dozen prosecutors and investigators and concluded that the Justice Department exhibited "“a pronounced failure to prosecute environmental crimes." Siegel, supra note 86 (quoting Jonathan Turley).

92. Kelly Richmond, Grand Jury Rebuffs FBI, Wants Congressional Immunity, States News Serv., Feb. 4, 1993, available in LEXIS, Nexis Library, SNS File.

93. Some legislators are not so eager to grant the jurors immunity. Charles Schumer (D-N.Y.), chairman of the House Judiciary Subcommittee on Crime and Criminal Justice, warns that "[g]ranting immunity in this instance would be an extraordinary precedent, and Congress must proceed with caution." Sachs, supra note 86.

94. The Rocky Flats case continues to spawn congressional investigations. The Oversight and Investigations Subcommittee of the House Energy and Commerce Committee, headed by full Committee Chairman John Dingell (D-Mich.), has decided to investigate, despite pleas from the White House to allow more time for an internal investigation. Kelly Richmond, Congress Launches New Probe of Rocky Flats Settlement, States News Serv., June 4, 1993, available in LEXIS, Nexis Library, SNS File. The ranking Republican on the Subcommittee, Rep. Dan Schaefer of Lakewood, Colorado, has taken a keen interest in the investigation. The investigation has already become controversial because the Attomey General has "agreed to the highly unusual step" of letting congressional staff question prosecutors at the Department of Justice about their cases. General Dingell, WALL ST. J., July 8, 1993, at A12 (editorial). So far, the investigation has thrust Congress into the limelight, pushing the grand jury further away from the center of attention. 


\section{B. Factors Contributing to the Grand Jury Revolt}

A number of factors contributed to this particular grand jury's rebellion: the depth of the investigation and the particular constellation of personalities encouraged familiarity with the issues and reduced deference to the prosecutor; the substantive law seemed to be applied more harshly to private citizens than to the government; and the judge's charge was inspiring but his subsequent explanation of grand jury powers confusing. While this particular confluence is rare, many individual factors are bound to be repeated, and the Rocky Flats grand jury's independence will likely embolden future grand juries. ${ }^{95}$

As the investigation wore on, jurors' respect for the prosecutor dwindled. The jurors were impaneled to investigate one particular case, so their attention was focused and they were able to build expertise. The length of the investigation made jurors more comfortable with the evidence and increasingly less comfortable with the prosecutors who presented it. According to several jurors who spoke with the press, the grand jury began as a typical servant of the prosecution but developed more independence as the investigation proceeded. $^{96}$ Partly, the specific personalities involved encouraged a declaration of independence. Jurors complained of Norton's condescending attitude; one juror claimed he " treated us like third-graders," another that he "'didn't give us credit for having any sense." 97 Foreman Wesley McKinley, a rancher, galvanized the jurors. He announced at one point: “'If you're going to let one government chickenshit lawyer tell you what to do, you're not part of America." 98

A similar populist feeling surrounded the substantive issues of the case in jurors' minds. The grand jury was probably affected by environmentalist and anti-nuclear rhetoric in the community, but even more potent was a belief that environmental laws were being applied unequally. Jurors felt that the government was exempting itself and its contractors while others paid heavy penalties. At one session, McKinley “waved a recent issue of Reader's Digest that described how a builder and his son were sent to prison for 21 months for disturbing a single half-acre of wetland." 99

95. There are already signs that grand juries are awakening. An Orange County, California grand jury recently issued a controversial report on illegal immigration in its area and concluded that there should be a three-year moratorium on all immigration. See Kevin Johnson \& Rene Lynch, O.C. Grand Jury Lacks Diversity, Critics Say, L.A. TIMES, June 28, 1993, at Al.

96. LaFraniere, supra note 82 .

97. Id. (quoting a grand juror).

98. Id. As Younger points out, an energetic foreman has frequently been the key to a grand jury's effectiveness. In the early twentieth century, George Putnam in New York City, Hovey Clark in Minneapolis, and B.P. Oliver in San Francisco "showed what a fearless foreman could accomplish in spearheading a municipal housecleaning." YouNGER, supra note 10, at 208.

Kenneth Peck, a Denver lawyer serving on the grand jury, also bolstered the jury's resolve by tirelessly researching legal issues. LaFraniere, supra note 82.

99. LaFraniere, supra note 82. "'Little guys and little companies sure get prosecuted for environmental crimes," McKinley has said. "“Our judge's instructions said no one is above the law. If that's not true, let's 
Jurors were also emboldened by the judge's charge and frustrated by his inability to explain the law once they had acted upon that charge. Finesilver had declared: "You must remember that you are not the prosecutor's agent. . . . You must not yield your powers nor forgo your independence of spirit . ... You would perform a disservice if you did not indict where the evidence warranted an indictment." 100 In an interview, McKinley said, "The judge told us to do as we saw right, and we believed that. The grand jury did its job. Now it's in the hands of the American people." 101 As the clash between jurors and prosecutor developed, the jurors turned to Chief Judge Finesilver with a written list of questions about their powers. The judge's visit to the grand jury room, however, merely confused jurors more; one said Finesilver's advice amounted to little more than "

Jurors have repeatedly expressed frustration with a judicial system that requests their services for two years yet denies them the power to make public their accusations. Seven jurors appeared on NBC's Dateline, and Shirley Kyle's comment was representative: "It makes me mad because if what we say or did doesn't mean anything, why did they choose to have a special grand jury?""103 Rocky Flats demonstrates how current secrecy rules thwart the people's ability to influence their own government and heighten the already towering level of exasperation with that government. ${ }^{104}$

go tell America, let's tell 'em what the deal is." Barry Siegel, Showdown at Rocky Flats, L.A. TJMES, Aug. 15, 1993, Magazine, at 22 (quoting McKinley).

100. Id.

101. Michael D. Lemonick, Sometimes It Takes a Cowboy: In the Showdown at Rocky Flats, Rockwell and Uncle Sam Face the Grand Jury that Won't Go Away, Time, Jan. 25, 1993, at 58.

102. LaFraniere, supra note 82 . Since the Supreme Court has given no guidance on the subject, the judge's nebulous response is not surprising. Law professors are divided on the question of grand jury powers in this situation, but strangely never mention presentments. Sara Sun Beale, a professor at Duke Law School and co-author of the most comprehensive treatise on grand jury law, see supra note 80, claims to be indifferent toward the grand jury disclosures from a policy standpoint but appears to believe that they violate Rule 6(e). Sachs, supra note 86. Richard Uviller, a professor at Columbia University School of Law, has made the dubious claim that Finesilver could have advised the grand jurors to fire Norton and appointed a special prosecutor. LaFraniere, supra note 82 . In contrast, Pace University's Gershman believes the jurors can do nothing without the prosecutor: "“[T] he bottom line is the prosecutor runs the show."' Id.

103. Dateline NBC (NBC television broadcast, Jan. 13, 1993) (Reuter Transcript Report).

104. One could compare the problem to that of "demoralization costs" described by Frank Michelman in the takings context. See Frank I. Michelman, Property, Utility, and Fairness: Comments on the Ethical Foundations of "Just Compensation" Law, 80 HARV. L. REV. 1165, 1214 (1967). When the government disturbs an established private interest, demoralization costs result. In the Rocky Flats case, the judge's assurance in the charge of the grand jury's independence created expectations that were finally dashed after a two-year investigation. In Michelman's model, demoralization costs include both those of immediate disappointment and those of "lost future production (reflecting either impaired incentives or social unrest) caused by demoralization of uncompensated losers, their sympathizers, and other observers disturbed by the thought that they themselves may be subjected to similar treatment on some other occasion." Id. For "production," one could substitute education about government or self-government itself. 


\section{A PRoposal for Clearing UP THE MUdDLE}

The confusion swirling around the Rocky Flats case could be eliminated by returning to grand juries their power to present government officials and contractors. ${ }^{105}$ To complement this basic reform, Congress should provide for declaratory judgment at the option of the accused, for grand jury staff, and for grand jury protection from premature discharge. The refurbished presentment power would further the Framers' goal of popular participation in and control over government.

\section{A. Restoring the Power To Present Government Officials and Contractors}

Together with restoring the presentment power, the legislature should adopt safeguards to ensure that it is not used indiscriminately. A certain amount of experimentation is necessary to determine how grand juries would exercise the revitalized power. To this end, presentments should, at least initially, be limited to those of government officials and contractors. ${ }^{106}$ As the Rocky Flats case shows, the need is most pressing in that area, and grand juries have long had a special mandate to inquire into the conduct of public officials.

\section{Government Oversight as a Traditional Grand Jury Function}

As noted above, grand juries traditionally have engaged in broad surveillance over government. The watchdog function, imported from England, grew stronger still in America. Justice Wilson could not emphasize the point more forcefully:

All the operations of government, and of its ministers and officers, are within the compass of [the grand jurors'] view and research. They may suggest publick improvements, and the modes of removing publick inconveniences: they may expose to publick inspection, or to publick punishment, publick bad men, and publick bad measures. ${ }^{107}$

105. Nixon's bill provided for presentments but did not name the power as such; the bill used the term "indictment" for an accusation approved by twelve or more jurors but not signed by a government prosecutor. (The prosecutor, however, would still have had to sign the "indictment" before a prosecution could begin.) Nixon's bill would also have allowed the grand jury to initiate an investigation themselves, rather than wait for the court or prosecutor to authorize an inquiry. S. 2086, 82d Cong., 1st Sess. (1951).

106. Contractors are included with officials because the government has significant incentives to turn a blind eye to the wrongdoing of those it has hired. First, the government has financial incentives. The contractor could do work more cheaply if it were not subject to legal constraints such as environmental controls; the government also might not want to spend the time and money necessary for adequate supervision. Second, the Executive might want to save face. The government generally likes to avoid admitting it has made a mistake in hiring the contractor or been lax in supervising contracted work.

107. 2 WILSON, supra note 23 , at 537. 
John Jay also emphasized the importance of federal grand jury inquiries into the conduct of public officials. ${ }^{108}$ Although federal grand juries' power to investigate and to criticize the conduct of public officials is not as great as that of many state grand juries, ${ }^{109}$ it is traditional, still useful, and should be preserved in the presentment power.

\section{Political Impartiality}

Grand jurors, who are not themselves permanent officials, are more likely to be free from bias than are prosecutors in cases involving officeholders. ${ }^{110}$ Judges, in particular, have long emphasized the impartiality of grand juries compared with other investigators when public officials come under suspicion. Experience on the bench no doubt makes judges acutely aware of the dangers of prosecutorial discretion in such circumstances. Justice Wilson early recognized the benefits of grand jury impartiality: "In the annals of the world, there cannot be found an institution so well fitted for avoiding abuses, which might otherwise arise from malice, from rigour, from negligence, or from partiality, in the prosecution of crimes."111 The grand jury's temporary membership helps to put it, in the words of Massachusetts Chief Justice Lemuel Shaw, "beyond the reach of fear or favor, or of being overawed by power or seduced by persuasion."

108. 3 The Correspondence ANd Public Papers of John Jay 394 (Henry P. Johnston ed., New York, G.P. Putnam's Sons 1891) ("Direct your attention also to the conduct of the national officers .....").

109. In some states, grand jury authority to criticize governmental officials is so great that jurors can initiate the removal from office of elected officials. See Stern, supra note 4, at 115 (discussing an Alaska grand jury report calling for the Governor's impeachment). Some states help to preserve this watchdog function by requiring automatic impaneling at the petition of the electorate. See 1 WAYNE R. LAFAVE \& Jerold H. ISRael, Criminal Procedure $\$ 8.1$, at $600 \mathrm{n.2}$ (1984). In the wake of the Pennsylvania legislature's 1938 attempt to suspend grand jury investigations of public officials once the House of Representatives had begun an inquiry, New York and Missouri inserted clauses into their constitutions providing that the grand jury power to investigate the conduct of public officials could never be suspended. N.Y. CONST. art. I, § 6; 3 JOURNALS OF THE CONSTITUTIONAL CONVENTION OF MISSOURI 13 (1944).

110. This is not to say, however, that grand juries are uniformly independent in such cases. A federal prosecutor's recent failed attempt to indict Sen. Charles Robb of Virginia on wiretapping charges suggests that the grand jury was swayed by Justice officials who in turn were motivated by political considerations. When jurors voted on an indictment that included both Robb and an associate, Bruce Thompson, they refused to indict Robb but did indict Thompson. However, the redrafted indictment that the grand jury approved indicated that Robb's involvement was extensive. Robert F. Howe \& Donald P. Baker, Grand Jury Declines To Indict Robb, WASH. POST, Jan. 13, 1993, at Al.

The grand jurors appear to have been influenced by a highly unusual visit from a top Justice Department official, Deputy Assistant Attorney General John C. Keeney, the day they considered the charges. Keeney, acting on instructions from Deputy Attorney General George Terwilliger, told the grand jurors that "the decision to indict the senator was theirs alone." Id. According to many sources, this was a signal that top Justice officials were attempting to head off the indictment but did not want to drop it formally for fear of seeming too lenient toward a politician. The grand jurors, sources speculate, got the message. Robert F. Howe \& Donald P. Baker, Justice Official's Appearance May Have Benefited Robb, WASH. POST, Jan. 14, 1993, at B1.

111. 2 WILSON, supra note 23 , at 534 .

112. Lemuel Shaw, Charge to the Grand Jury, 8 AM. JuRIST 216, 217 (July 1832). See Wright, supra note 3, at 478 . This concept of rotation in office preventing the accumulation of special interests was influential among Jacksonians and is enjoying a revival today among supporters of term limits. Rotation 
California ${ }^{113}$ Justice Harlan noted that the grand jury, being free from control by the electorate and from public clamor, was ideally suited to impartial and nonmalicious consideration of charges. ${ }^{114}$ In order to maintain public confidence in the criminal law system, the grand jury should have the power to present public officials and contractors.

This approach would solve some of the problems of possible partiality on the part of the prosecutor in the Rocky Flats case. Grand jurors, unlike a U.S. Attorney, can avoid even the appearance of impropriety when a U.S. agency or contractor is under investigation. The people should not rely solely on the Executive to police itself in such cases. Nor is the legislature entirely successful at performing this function; investigative subcommittees have obvious political biases, ${ }^{115}$ magnified by the often public nature of their hearings, while the independent counsel law has provoked criticism on both political and constitutional grounds. ${ }^{116}$ Grand juries have significant advantages over other methods of oversight.

\section{Executive Initiation of Prosecution}

Grand jury presentments would not interfere with the long-established principle that prosecution in federal courts is uniquely dominated by the

also had the advantage of allowing more people to be educated in the ways of government by governing themselves. See Akhil R. Amar, The Bill of Rights as a Constitution, 100 YALE L.J. 1131, 1189 (1991).

113. 110 U.S. 516, 538 (1884) (Harlan, J., dissenting).

114. Id. at 554-55; see also Losavio v. Kikel, 529 P.2d 306, 308 (Colo. 1974) ("Where corruption is charged, it is desirable to have someone outside of the administration [i.e., the grand jury] act, so that the image, as well as the fact, of impartiality in the investigation can be preserved and allegations of cover-up or white-wash can be avoided.").

115. See the discussions of the Investigations and Oversight Subcommittee of the House Science, Space, and Technology Committee supra note 89 and accompanying text, and the House Energy and Commerce Committee supra note 94.

116. Special prosecutors have also been criticized for wasting taxpayers' dollars. See, e.g., Morrison v. Olson, 487 U.S. 654, 714 (1988) (Scalia, J., dissenting); Max Boot, Walsh's Iran-Contra Probe Comes to an End as Whimper, Not Bang, CHRISTIAN SCI. MONITOR, Dec. 9, 1993, at 1 (criticizing Independent Counsel for expenses such as suite at Watergate hotel). 
Executive. ${ }^{117}$ Presentments cannot initiate a prosecution without the consent of the Executive. ${ }^{118}$

\section{School for Civic Duty}

Several authors have recently noted an earlier emphasis on jury service as a means of educating the people in the ways of democratic government. ${ }^{119}$ Tocqueville believed that the jury "should be regarded as a free school which is always open and in which each juror learns his rights, comes into daily contact with the best-educated and most-enlightened members of the upper classes, and is given practical lessons in the law."120 Francis Lieber, a student of Story's and an influential commentator on the Constitution, ${ }^{121}$ noted that along with this increased knowledge of the law came increased respect for and attachment to the government. Jury service "binds the citizen with increased public spirit to the government of his commonwealth, and gives him a constant and renewed share in one of the highest public affairs, the application of the abstract law to the reality of life-the administration of justice." ${ }^{22}$ Indeed, the Rocky Flats jurors did learn a great deal about the

117. As Justice Scalia and even critics of his dissent in Morrison v. Olson recognize, federal prosecutorial authority is exceptionally centralized. Morrison v. Olson, 487 U.S. at 710 . For a lengthy list of cases upholding tight executive control over prosecution, see Krent, supra note 27, at 277 n.13. However, Justice Scalia goes too far with his categorical statement that "the President's constitutionally assigned duties include complete control over investigation and prosecution of violations of the law . . .." 487 U.S. at 710. Krent's article points to some exceptions to the rule, including congressional and grand jury investigations. Krent, supra note 27, at 281-83, 292.

Although Dangel attempts to show that the Framers did not view prosecutorial power as a core executive function, the most that can be said is that they pronounced no strong opinion one way or the other. Dangel, supra note 20. Prosecution was one of those areas-like many others connected to the federal courts-left to subsequent determination, and judicial decisions have determined that certain aspects of criminal law enforcement have "long been regarded as the special province of the Executive Branch." Heckler v. Chaney, 470 U.S. 821,832 (1985).

As the authors of one treatise point out, many states give the grand jury more power over prosecution. Most jurisdictions permit the grand jury to initiate prosecution by indictment even though the prosecutor opposes prosecution. Some require only that the foreman, acting on behalf of the grand jury, sign the indictment. Others have provisions similar to Rule 7 requiring the prosecutor's signature, but they view that requirement as mandating essentially a "clerical act" by the prosecutor.

KAMISAR ET AL., supra note 10 , at 845.

Most states also have statutes allowing the appointment of a special prosecutor when a grand jury investigation relates to the operation of the prosecutor's office. In addition, several states have provisions allowing such an appointment after a showing that the prosecutor has not given the grand jury adequate legal or investigatory assistance. See LAFAVE \& ISRAEL, supra note 109, § 8.4, at 625 .

118. See supra text accompanying notes $29-30,66$.

119. See Amar, supra note 112, at 1186-87; Wright, supra note 3, at 479-81.

120. 1 Alexis DE TOCQUeVIlle, DEMOCRACY IN AMERICA 252 (J.P. Mayer \& Max Lerner eds. \& George Lawrance trans., Harper \& Row 1966) (1835). On judges' and justices' deliberate efforts to educate through their grand jury charges, see Katz, supra note 21 , at 1053.

121. Wright, supra note 3 , at 478 n.66.

122. FRANCIS Lieber, ON CIVIL LiberTy AND SELF-GovernMENT 236 (Theodore D. Woolsey ed., Philadelphia, J.B. Lippincott 1874). He also noted, more ominously for our time, that jury service "is with the representative system one of the greatest institutions which develop the love of the law, and without this love there can be no sovereignty of the law in the true sense." Id. at 237. 
legal system and their duties as citizens in the course of their long service. ${ }^{123}$ Whether they feel more attached to the government is another matter.

These jurors are disturbed by what they perceive as hypocrisy in a judicial system that claims to value their knowledge and.opinions while denying them the opportunity to make their determinations known when a serious conflict arises. Jurors learn not respect for, but frustration with, the system if they feel their efforts, particularly after a long investigation, are considered unworthy of official recognition. They tend to become cynical about the process of government and either refuse to participate seriously or, like the Rocky Flats grand jury, relieve their feelings through leaks to the press. ${ }^{124}$ Legitimating presentments would indicate to jurors that the government takes their opinions seriously and values their new-found knowledge. The grand jury could then once again function as Justice Wilson described the institution: "a great channel of communication, between those who make and administer the laws, and those for whom the laws are made and administered."125

\section{B. Providing for Declaratory Judgment}

The greatest problem with presentments is the lack of opportunity for the accused to answer in a judicial forum. This deficiency has disturbed judges and contributed to judicial disapproval of presentments. One of the harsher descriptions follows:

A presentment is a foul blow. It wins the importance of a judicial document; yet lacks its principal attributes-the right to answer and to appeal. It accuses, but furnishes no forum for a denial. No one knows upon what evidence the findings are based. An indictment may be challenged, even defeated. The presentment is immune. It is like the "hit and run" motorist. Before application can be made to suppress it, it is the subject of public gossip. The damage is done. The injury it may unjustly inflict may never be healed. ${ }^{126}$

Such dire predictions nearly became reality in Application of United Electrical, Radio \& Machine Workers. ${ }^{127}$ As described above, the grand jury and

123. McKinley described his initial ignorance: "I didn' $t$ know what a grand jury did. When I couldn"t find the courthouse for four hours the first day, I knew I was in trouble." Dateline NBC, supra note 103. By the end of his odyssey as foreman, he was an outspoken advocate of grand jury powers.

124. One author suggests that grand juries should be permitted to give interviews to the press. Tim A. Baker, Note, Grand Jury Secrecy v. the First Amendment: A Case for Press Interviews of Grand Jurors, 23 VAL. U. L. REv. 559 (1989). This solution, however, would not give the official sanction provided for in the Constitution.

125. 2 WILSON, supra note 23 , at 537.

126. People v. McCabe, 266 N.Y.S. 363, 367 (1933). Chief Judge Finesilver cited this passage in his order denying a motion to release documents the grand jury drafted. In re Grand Jury Proceedings, Special Grand Jury 89-2 (Rocky Flats Grand Jury), 813 F. Supp. 1451, 1463 (D. Colo. 1992).

127. 111 F. Supp. 858 (S.D.N.Y. 1953). 
prosecutor essentially colluded to prevent union leaders from answering charges made in a presentment. ${ }^{128}$ In United States $v$. Cox, the combination shifted: the judge and the jury favored accusation, while the prosecutor protested. In his concurrence, Judge Wisdom warned of the dangers of allowing charges to hang over the heads of the accused for an indefinite period. ${ }^{129}$ The protection of the accused before trial is frequently a reason given for grand jury secrecy laws. ${ }^{130}$

To prevent such injustices and yet allow the grand jury the power of presentment, Congress should turn to a proposed reform from the field of libel law and provide for declaratory judgment. ${ }^{131}$ The accused could initiate an action for declaratory judgment to determine whether the grand jury's presentment met a certain standard of proof. Two alternative models for this

128. See supra text accompanying notes $61-64$.

129. 342 F.2d 167, 189 (5th Cir. 1965) (Wisdom, J., concurring specially). Several authors have suggested various ways to protect named individuals against unjust reports alleging noncriminal conduct. Beale and Bryson believe that the subject of a critical report has a due process right to appear before the grand jury, but this approach would afford scant protection against biased jurors. 1 BEALE \& BRYSON, supra note 80, $\$ 3: 04$. Stern emphasizes prepublication review, in which the court examines a report before it is made public and has the power to seal it. Stern, supra note 4 , at 126-27. This procedure provides some protection for the subject of criticism, although it would not resolve the problem in Cox-like situations where the judge supports the questionable allegation. Federal grand jury reports are carefully controlled. See 18 U.S.C. $\$ \$ 3331-3334$ (1988) (providing for grand jury reports of noncriminal misconduct of public officials); supra note 87.

However, a presentment of criminal charges is a different matter-one so sensitive that these authors avoid mentioning it altogether. Despite the constitutional authorization of grand jury presentments, Stern says "[t]he use of a report to accuse a public official of criminal misconduct may also be subject to constitutional challenge as a violation of due process and the fifth amendment right to indictment." Stem, supra note 4 , at 105 n.124.

130. In his summary of the rationale underlying traditional grand jury secrecy rules, Justice Brennan prominently listed the prevention of "disclosure of derogatory information presented to the grand jury against an accused who has not been indicted." Pittsburgh Plate Glass Co. v. United States, 360 U.S. 395, 405 (1959) (Brennan, J., dissenting).

131. See Marc A. Franklin, A Declaratory Judgment Alternative to Current Libel Law, 74 CAL. L. REV. 809, 812-13 (1986). Grand jurors are, and were traditionally, immune from libel suits. See United States v. Briggs, 514 F.2d 794, 808 (5th Cir. 1975); RESTATEMENT (SECOND) OF TORTS $\$ 589$ (1977). (California is the exception. See CAL. PENAL CODE $\$ 930$ (West 1985) (denying immunity to grand jurors for comments on a person who has not been indicted).) The same remedy could be applied to untruthful petitions, which would also have the potential to become "hit and run" vehicles if the Supreme Court were to recognize their traditional, nearly absolute, immunity from libel actions. See Eric Schnapper, "Libelous" Petitions for Redress of Grievances-Bad Historiography Makes Worse Law, 74 IowA L. REV. 303 (1989) (arguing that McDonald v. Smith, 472 U.S. 479 (1985), was wrongly decided because petitions were absolutely immune from libel actions at the time of ratification of the Bill of Rights); Norman B. Smith, "Shall Make No Law Abridging . . .": An Analysis of the Neglected, but Nearly Absolute, Right of Petition, 54 U. CIN. L. REV. 1153 (1986).

Note that grand jury noncriminal presentments were often petitions for redress of grievances. See supra note 25 . Insulating petitions and grand jury presentments from libel laws helped ensure that the most significant channels of communication between rulers and ruled would remain open. The right to petition is closely linked to the other First Amendment rights of speech, the press, and assembly, id. at 1168-69; the grand jury presentment also is closely linked to these "expressive" rights.

As Judge Leval notes, the Framers frowned on secrecy and strove to encourage the free spread of ideas. The "underlying objectives" of the Copyright Clause, for example, "parallel those of the first amendment"; the clause was intended "'[t]o promote the Progress of Science and the useful Arts."' Pierre N. Leval, Commentary, Toward a Fair Use Standard, 103 HARV. L. REv. 1105, 1135 (1990) (quoting U.S. CONST. art. I, \& 8, cl. 8). 
proceeding follow: one focuses on the good faith of the grand jury and prosecutor, the other on the substantive accuracy of the accusation.

The first model is less elaborate and resembles review of a warrant. The standard would be probable cause, ${ }^{132}$ and the accused would bear the burden of persuasion. The record used by the fact-finder would be the grand jury record. Recall that a court reporter must be present at all grand jury sessions except deliberations and votes. ${ }^{133}$ Opportunities to supplement this record should be few. ${ }^{134}$ This model would avoid the length and complexity of triallike procedures.

Alternatively, the action could use procedures more like those of an ordinary civil trial. The second model would use a standard of preponderance of the evidence. The grand jury presentment and record would constitute a prima facie case supporting the accusation. The accused could then introduce evidence tending to show lack of guilt, and opposing counsel could introduce further evidence. This model, although more complicated than the first, would allow the accused a full opportunity to be heard. ${ }^{135}$

132. Grand juries commonly use a probable cause standard to decide whether to indict. See Stern, supra note 4 , at $103 \mathrm{n} .114$.

133. See supra note 78 .

134. The accused should be allowed to introduce additional evidence in three situations. The first involves perjured testimony. If the accused can show by clear and convincing evidence that a witness committed perjury in giving material testimony, that evidence should come into the record. Opposing counsel should be able to introduce evidence that no perjury was committed. If the prosecutor has known about or discovers such perjury, he or she should have a duty to disclose it to the accused. Most federal courts have held that "deliberate use of perjured or false evidence material to the grand jury's determination will invalidate the indictment unless there is sufficient untainted evidence in the record to support the charges." BEALE \& BRYSON, supra note 80, at $\$ 10: 08$ (emphasis added). See, e.g., Coppedge v. United States, 311 F.2d 128, 131-32 (D.C. Cir. 1962), cert. denied, 373 U.S. 946 (1963). The same should be true of presentments, and non-deliberate use should be remedied as well.

Second, other grounds that are sufficient to quash an indictment should suffice to quash a presentment. Federal courts, however, are reluctant to invalidate indictments. They generally refuse to consider challenges to an indictment based on insufficiency of evidence. See, e.g., Costello v. United States, 350 U.S. 359, 362 (1956) (upholding indictment based solely on hearsay; grand jurors "were free to make their presentments or indictments on such information as they deemed satisfactory"); United States v. Calandra, 414 U.S. 338, 350 (1974) (upholding indictment based on evidence obtained in violation of Fourth Amendment). But some federal courts have invalidated indictments for lack of admissible evidence in certain situations. See BEALE \& BRYSON, supra note 80, \$ 10:20. The most significant of these are cases in which the grand jury itself has violated the constitutional rights of the accused. See, e.g., United States v. North, 920 F.2d 940, 948-49 (D.C. Cir. 1990) (stating that indictment based on immunized testimony of accused is tainted), cert. denied, 111 S. Ct. 2235 (1991); United States v. Helstoski, 635 F.2d 200, 201 (3d Cir. 1980) (dismissing indictment because introducing evidence about Congressman's legislative activities violated Article I Speech and Debate Clause).

The third situation concerns evidence that makes a finding of probable cause unreasonable. The court should be strict in interpreting such a standard. The standard would be similar to that used in evaluating motions for a new trial under Fed. R. Crim. P. 33 based on newly discovered evidence: that the newly discovered evidence would probably produce an acquittal. See, e.g., United States v. Thompson, 493 F.2d 305, 310 (9th Cir. 1974), cert. denied, 419 U.S. 834 (1974); Ashe v. United States, 288 F.2d 725, 733 (6th Cir. 1961). Again, the prosecutor would have a duty to disclose such evidence if known to him or her.

135. This procedure would help to prevent the fact-finder from relying too heavily on the grand jury record. Ordinarily, the grand jury only hears one side of the case. See Peter Arenella, Reforming the State Grand Jury System: A Model Grand Jury Act, 13 RuTGERS L.J. 1, 9 (1981) ("The most obvious defect [of the federal and state grand jury systems] is the grand jury's complete dependence on the prosecutor for all its information, advice, and direction."). 
Under either model, the action for declaratory judgment should carry a statute of limitations, preferably of about six months. If the presentment was not challenged or if it survived challenge, the government could prosecute the case within one year after the presentment was made. ${ }^{136}$ To do so, the prosecutor would simply sign the presentment, thus transforming it into an indictment, and the usual procedures would follow. If the presentment did not survive challenge, the prosecutor would need to seek a new grand jury accusation before prosecuting.

\section{Allowing the Grand Jury Appropriate Staff}

An important reason why the grand jury has lost ground compared to judges, prosecutors, and legislators is its lack of staff. Counsel is particularly important. Lay jurors encounter many problems requiring legal expertise, and if they are to become more independent they must have a source of legal advice other than the prosecutor or the judge. The declaratory judgment procedure assumes that the presentment is already in proper legal form, since making changes raises the difficult question, discussed in Gaither, of what changes are substantial enough to require resubmission to the grand jury for its approval. Providing the grand jury with counsel would enable it to make presentments that can serve, without alteration, as formal charging documents.

Several authors have noted the need for special staff to serve the grand jury. ${ }^{137}$ Hawaii's constitution even provides for "independent counsel appointed ... to advise the members of the grand jury regarding matters brought before it." ${ }^{138}$ Nixon recognized the importance of professional assistance for the grand jury and provided for such staff in his bill. ${ }^{139} \mathrm{~A}$ scheme similar to his would be appropriate: at the request of twelve or more jurors, the judge who impaneled the jury would appoint counsel and special investigators, not exceeding a certain number. Expenditures would be controlled by fixing daily rates of compensation by statute. In addition, the court should automatically provide counsel when the grand jury wishes to

136. After that year, the government would have to turn to another grand jury for a presentment or indictment. Such a limitation would address Judge Wisdom's concern about the possibility of a presentment hanging over someone's head that the government could activate at any time. Of course, the statute of limitations for the underlying crime would still be relevant. A prosecutor would have to sign a presentment, thus transforming it into an indictment, within the period prescribed by the statute of limitations for the particular crime.

137. See Wright, supra note 3, at 486; Dession \& Cohen, supra note 51, at 696; see also Harold W. Kennedy \& James W. Briggs, Historical and Legal Aspects of the California Grand Jury System, 43 CAL. L. REV. 251, 262-65 (1955).

138. HAW. CONST. art. I, § 11; cf. N.C. GEN. STAT. § 15A-624 (1992) (stating that presiding judge will be legal advisor to grand jury).

139. S. 2086, 82d Cong., 1st Sess. (1951). 
make a presentment, to ensure that it is drafted correctly (although in such cases the jurors would likely make the request anyway). ${ }^{140}$

\section{Limiting Judicial Discretion To Discharge Grand Juries}

Another difficulty faced by a grand jury attempting to issue a presentment is the great judicial discretion concerning discharge. Rule 6 appears to grant judges absolute discretion over discharge, ${ }^{141}$ but that discretion is modified by a handful of decisions holding that a district court should not discharge a grand jury without cause in order to prevent an indictment. ${ }^{142}$

Although Chief Judge Finesilver did not immediately discharge the grand jury and allowed it to continue to meet after the prosecutor had settled the case, other judges might not be so respectful of the grand jury. The federal grand jury needs greater protection from premature discharge if it is to fulfill its function of ferreting out government wrongdoing. Rule $6(\mathrm{~g})$ should be amended to prohibit a court from discharging a grand jury if twelve jurors give notice that they wish to continue an investigation, subject to the statutory limitation of eighteen months. ${ }^{143}$

\section{CONCLUSION}

The grand jury still has the potential to become, as the Framers envisioned, a "great channel of communication" between rulers and ruled; indeed, it helps to break down the distinction between the two. But to realize this vision, Congress and the courts must go beyond ill-considered and piecemeal reform. Congress, in particular, should not become so distracted by the substantive issue of environmental crimes and by its own investigations that it forgets who brought Rocky Flats to its attention in the first place. A statute is needed that precisely defines the grand jury presentment power as against indictments and reports. Secure in their powers and in the knowledge that their opinions would be respected, grand jurors could once again directly voice the will of the people.

140. This counsel could also serve as the lawyer opposing the accused in a declaratory judgment action if one were brought. If for some reason the grand jury's counsel could not participate, the court could simply appoint counsel.

141. See supra note 80 .

142. See, e.g., In re Investigation of World Arrangements with Relation to Prod., etc., of Petroleum, 107 F. Supp. 628 (D.D.C. 1952). Many states now permit an early discharge only where justified by "cause." See 1 LAFAVE \& ISRAEL, supra note $109, \S 8.4$, at 626.

143. The latter limitation is necessary in order to prevent indefinitely self-perpetuating grand juries. The Nixon bill attempted to resolve problems concerning discharge with the following provision: "Whenever a grand jury shall give notice to the court that it wishes to undertake an inquiry, such grand jury shall not be discharged by the court prior to such time as the court shall receive notice that such inquiry has been completed." S. 2086, 82d Cong., 1st Sess (1951). The notice was to be signed by twelve or more jurors. Id. The solution outlined in the text would probably be simpler to apply because it would require no prior notice that the grand jury wished to undertake an inquiry. 